\title{
Pengaruh Orientasi Kewirausahaan Terhadap Kinerja Perusahaan: Studi Kasus Umkm Pendukung Wisata Kuliner Di Provinsi Kepulauan Bangka Belitung
}

\author{
Kania Ratnasari', Levyda Levyda ${ }^{2}$ \\ Fakultas Ekonomi dan Bisnis, Universitas Sahid ${ }^{12}$
}

\begin{abstract}
The purpose of this study was to determine the entrepreneurial orientation and performance of MSMEs in Bangka Belitung Province and to find out whether entrepreneurship orientation had an influence on the performance of MSMEs. Respondents in this study are the SMEs in the Province of Bangka Belitung while the random sampling is 32 SMEs. The analytical method used is quantitative descriptive data analysis. The research variables consist of 2 (two) namely Entrepreneurship Orientation and Business Performance, each of which has indicators. Indicators of entrepreneurial orientation are Innovative, Risk Taking, Proactiveness, Competitive Aggressiveness and Autonomy while indicators of business performance are Sales Growth, Competitive Advantage and Consumer Satisfaction. The results of this study are for entrepreneurial orientation variables including the high category with the highest average value is the indicator of competitive Aggressiveness while the lowest average value is the indicator Dare to take risk. Then on the variable business performance including a good category with the highest average value is the Consumer Satisfaction indicator while the lowest average value is on the indicator of Sales Growth.
\end{abstract}

Keywords: Entrepreneurship orientation, Business performance, UMKM, Bangka Belitung Province

\begin{abstract}
Abstrak
Analisis ini bertujuan untuk mengetahui orientasi kewirausahaan dan keberhasilan Usaha Mikro Kecil Menengah (UMKM) di Kepulauan Bangka Belitung, dan untuk mengetahui apakah orientasi kewirausahaan berpengaruh terhadap kinerja UMKM tersebut. Asal mula penelitian ini adalah peserta UMKM dari Provinsi Bangka Belitung dan dipilih secara acak 32 peserta UMKM. Pendekatan yang digunakan dalam penelitian ini adalah pengolahan data kuantitatif deskriptif. Faktor studi yang ada memberikan 2 (dua) metrik, yaitu orientasi kewirausahaan dan kinerja usaha. Indikator yang berorientasi pada orientasi kewirausahaan adalah Inovasi, Pengambilan Resiko, Proaktif, Agresifitas Persaingan dan Otonomi sedangkan indikator Kinerja Usaha adalah Pertumbuhan Penjualan, Keunggulan Bersaing dan Kepuasan Konsumen. Hasil penelitian menunjukkan bahwa indikator orientasi kewirausahaan berada pada peringkat kuat dengan nilai rata-rata maksimum pada indeks kepentingan strategis dan nilai rata-rata terendah pada indeks pengambilan risiko sedangkan pada indikator kinerja usaha dengan skor rata-rata tertinggi terdapat pada indikator "Kepuasan Konsumen" dan skor rata-rata terendah terdapat pada indikator "pertumbuhan penjualan".

Kata Kunci: Orientasi kewirausahaan, Kinerja usaha, UMKM, Provinsi Bangka Belitung
\end{abstract}




\begin{tabular}{lll}
\hline DOI & $:$ & http://dx.doi.org/10.32503/jmk.v6i2.1267 \\
Sejarah Artikel & $:$ & Artikel diterima (1 April 2021); direvisi (16 April 2021); \\
& disetujui (2 Mei 2021) \\
Email & $:$ & kania.ratnasari@ yahoo.com \\
\hline
\end{tabular}

\section{Pendahuluan}

Dalam perkembangan perekonomian serta prospek pekerjaan Indonesia, pembangunan di sektor UMKM merupakan faktor yang signifikan. UMKM diantisipasi untuk terus berkembang karena telah memberikan kontribusi yang signifikan bagi kelancaran perekonomian nasional Indonesia. UMKM sendiri merupakan bidang pasar yang dapat mendorong perekonomian nasional untuk memasukkan devisa, yang dapat membangun lapangan kerja bagi penduduk dan menjadi mid-stream mengingat pilar ketenagakerjaan, mengingat jumlah tenaga kerja pada UMKM bisa mencapai 97,33 \% pada tahun 2012, lalu menurun. Manfaat pengangguran bagi penyandang cacat (Rahmana et al., 2012)

Berdasarkan data Kementerian Koperasi dan UMKM pada tahun 2017, diukur dari jumlah unit dan dari total jumlah seluruh pelaku usaha di Indonesia, pangsa pasar UMKM sekitar 99,99\% atau sekitar 62,9 juta unit, sebanding dengan perusahaan besar. Yang relevan hanya 0,01\% dimana itu dianggap sebesar 5400 unit. Adapun usaha mikro dapat memperoleh sebanyak 107,2 juta tenaga kerja atau sekitar 89,2\%, kemudian perusahaan kecil mencapai 5,7 juta atau sekitar 4,74\%, kemudian perusahaan menengah mencapai 3,73 juta atau sekitar 3,11\%, sedangkan perusahaan besar dapat memperoleh 3,58 juta. Artinya UMKM terintegrasi mampu memperoleh sebanyak $97 \%$ tenaga kerja nasional, dimana perusahaan besar dapat mampu memperoleh sebanyak 3\% angkatan kerja nasional. UMKM yang ada didalam UU No.3. 20/2008 mengatur bahwa UMKM merupakan perusahaan kecil dan atau menengah yang mana dipunyai dan dimanfaatkan oleh satu orang, atau dipunyai oleh beberapa kelompok kecil orang yang memiliki pendapatan tertentu. Berikut adalah data tentang standar kekayaan dan pendapatan dalam undangundang tersebut.

Tabel 1. Aset \& Omset bagi UMKM

\begin{tabular}{ccc}
\hline \multirow{2}{*}{ Ukuran Usaha } & \multicolumn{2}{c}{ Kriteria } \\
\cline { 2 - 3 } & Aset & Omset \\
& (Tidak termasuk tanah \& & \\
\hline Bangungan tempat usaha \\
\hline Mikro & Maks Rp 50 juta & Maks Rp 300 juta \\
\hline Kecil & $>$ Rp 50 juta - Rp 500 juta & $>$ Rp 300 juta - Rp 2,5 miliar \\
\hline Menengah & $>$ Rp 500 juta - Rp 10 miliar & $>$ Rp 2,5 miliar - Rp 50 miliar \\
\hline Besar & $>$ Rp 10 miliar & $>$ Rp 50 miliar \\
\hline
\end{tabular}

Sumber: UU No.20/2008 
UMKM non pertanian ada tiga jenis (tiga), dan jumlah peserta komersialnya termasuk yang terbaik dalam pendapatan ekonomi nasional, yaitu: (1) Perdagangan besar dan eceran. Bisnis ini merupakan bisnis penjualan barang, dan tidak ada proses perubahan bentuk perdagangan produk. Contohnya adalah pedagang permen yang membeli permen dalam jumlah banyak secara eceran untuk dijual kembali, dan / atau pedagang keripik yang memperoleh keripik yang diproduksi oleh beberapa IRT atau ibu-ibu pada rumah tangga, lalu mengemasnya, memberikan label dan menjualnya secara ecer. (2) Menyediakan papan dan penginapan serta makan. Bisnis ini terdiri dari berbagai jenis bisnis, seperti restoran, restoran, katering, food court, food court, kedai kopi, dll. Kategori ini juga mencakup industri katering yang menyediakan makanan untuk sebuah kegiatan atau kebutuhan akan logistik, seperti makanan yang digunakan pada beberapa alat trasnportasi seperti misalnya kereta api, kapal laut dan pesawat. (3) Industri pengolahan. Kategori ini mencakup beberapa aspek produksi yang merubah wujud bahan baku mentah menjadi produk jadi yang dapat digunakan atau dikonsumsi. Misalnya, bidang sandang yang semula daging diubah menjadi sop daging, dan aspek konveksi pada awalnya bertransformasi menjadi berbagai industri sandang atau minuman. Industri pengemasan awalnya buah murni. Dikonversi menjadi minuman jus dalam kemasan (Kristiyanti \& Rahmasari, 2015)

Menurut data dari BPS, diperoleh angka sebesar 3,4 juta UMKM di industri pengolahan yang sebagian besar menuju di 5 (lima) sektor industri yaitu kuliner berupa makan dan minum sebesar 44,9\%; kerajinan kayu dan anyaman 19,9\%; Tekstil dan pakaian meningkat $14,4 \%$; mineral non-logam seperti tepung, industri mika turun 6,9\%; terakhir, furnitur, terhitung 3,5\% (BPS Provinsi Bangka Belitung, 2019)

Tabel 2. Pertumbuhan UMKM Di Bangka Belitung

\begin{tabular}{l|c|c}
\hline \multicolumn{1}{c|}{ Kabupaten/Kota } & Tahun 2017 & Tahun 2018 (15 Feb 2018) \\
\hline Pangkalpinang & 17.308 & 10.000 \\
Bangka & 3.617 & 52.000 \\
Belitung & 20.491 & 16.881 \\
Bangka Tengah & 39.754 & 21.515 \\
Bangka Barat & 23.813 & 22.731 \\
Bangka Selatan & 6.593 & 47.122 \\
Belitung Timur & 18.891 & 10.260 \\
\hline Jumlah & $\mathbf{1 3 0 . 4 6 7}$ & $\mathbf{1 8 0 . 5 0 9}$ \\
\hline
\end{tabular}

Sumber: Dinas Koperasi, UKM Provinsi Kepulauan Bangka Belitung, 2018

Mengingat Kepulauan Bangka Belitung memiliki kekayaan sumber daya laut dan perkebunan yang sangat luas, maka Kepulauan Bangka Belitung termasuk provinsi yang memiliki potensi besar untuk produksi UMKM di wilayahnya. Pemerintah Belitung Bangka bekerja keras membangun pariwisata sejalan dengan pengembangan UMKM. Percepatan kemajuan industri pariwisata sudah seharusnya dapat maju beriringan dengan pertumbuhan pada UMKM, dan UMKM harus memimpin atau mengejar kemajuan industri pariwisata Bangka Belitung. 
Tabel 3. Jenis Usaha di Provinsi Bangka Belitung

\begin{tabular}{c|l|c|c}
\hline No & Jenis Usaha & Jumlah (Unit) & Persentase (\%) \\
\hline 1 & Mikro & 5.120 & 56,44 \\
\hline 2 & Kecil & 3.770 & 41,56 \\
\hline 3 & Menengah & 106 & 1,17 \\
\hline 4 & Besar & 75 & 0,83 \\
\hline \multicolumn{2}{c}{ Jumlah } & 9.071 & 100 \\
\hline
\end{tabular}

Sumber : DISPERINDAG Provinsi Kepulauan Bangka Belitung, 2015

Dinas Koperasi dan UMKM Provinsi Bangka Belitung melaporkan sekiranya Usaha Kecil dan Menengah (UMKM) telah mendirikan 5 (lima) sektor utama, yaitu: industri dalam hal pengolahan; pertanian serta perdagangan dan juga restoran; pertambangan; dan bangunan. UMKM menghadapi 10 (sepuluh) karakteristik dan tantangan, yaitu: (1) Peserta komersial selalu berupaya untuk bertahan hidup; (2) berpenghasilan rendah; (3) kurangnya legalitas komersial; (4) lokasi pasar yang tidak jelas; (5) keterampilan kewirausahaan yang buruk; (6) daya saing rendah; (7) produktivitas rendah; (8) Kemasan komoditas dasar; (9) Sertifikasi halal; (10) Sertifikasi SNI.

Keberhasilan usaha kecil dan menengah di Belitung Bangka dapat dilihat sebagai sumber pendapatan bagi sebagian besar penduduk negara. Namun demikian, berbagai permasalahan yang dihadapi oleh pelaku UMKM telah memuncak pada sebagian besar UMKM yang enggan atau tidak mau sepenuhnya meningkatkan keuntungannya sehingga tidak dapat memenuhi kebutuhan hidup dan perusahaan dengan baik. Pendapatan usaha sangat diperlukan untuk berwirausaha, namun pelaku usaha harus mau mengkonsolidasikan pendapatan usahanya masing-masing untuk menopang kesuksesan UMKM. Mencakup pertumbuhan pendapatan, manfaat, dan loyalitas konsumen. Oleh karena itu, kesuksesan pasar yang sukses mencakup kewirausahaan yang baik. Rendahnya keberhasilan UMKM salah satunya ditengarai karena lemahnya kepribadian pengusaha dan peran manajemen terbaik dalam mengelola usaha dalam iklim pasar yang kompetitif (Sudarsono, 2015).

Orientasi kewirausahaan dikenal sebagai pendekatan baru dalam pembaruan kinerja perusahaan. Menurut (Sofyan, 2017) bahwa orientasi kewirausahaan merupakan kemungkinan seseorang dapat melakukan beberapa hal, seperti aktif berinovasi dan berani mengambil risiko untuk dapat memulai dan mengelola suatu usaha. Konsep bisnis dapat dibagi menjadi beberapa perilaku, seperti inovasi (inovasi), pengambilan risiko, inisiatif (proaktif), agresivitas kompetitif dan otonomi (mandiri). Menurut (Ameliawati \& Nugraheni, 2015) bahwa kinerja merupakan kunci dari hasil kerja dan hasil kerja. Sasaran keberlangsungan hidup perusahaan adalah: (1) bertahan (survive); (2) memperoleh laba (pendapatan) dan (3) berkembang (tumbuh), apabila perusahaan atau badan usaha dapat dan dapat dan dapat berkinerja dengan baik maka dapat tercapai Dan mencapai tujuan tersebut (Wahyu \& Ranto, 2016).

Penelitian ini menitikberatkan pada UMKM yang ada di Bangka Belitung yang mana belum banyak diteliti mengenai UMKM tersebut dalam menggunakan dan menerapkan orientasi kewirausahaan, maka UMKM yang menggunakan dan menerapkan orientasi kewirausahaan tentunya akan memiliki kinerja bisnis yang 
lebih baik.

Adapun tujuan dari penelitian ini adalah untuk mengetahui orientasi kewirausahaan dan kinerja usaha pada UMKM Bangka Belitung serta untuk mengetahui pengaruh antara orientasi kewirausahaan terhadap kinerja usaha UMKM Bangka Belitung.

\section{Metode Penelitian}

Komunitas yang digunakan dalam analisis ini adalah peserta UMKM di Kabupaten Bangka Belitung yang didampingi dengan sensus 32 peserta UMKM. Dalam skenario ini, proses pengumpulan data dilakukan dengan memberikan kuesioner kepada pelamar UMKM, dimana kuesioner tersebut terdiri dari beberapa pernyataan tertutup yang kemudian ditutup dengan wawancara. Pendekatan yang digunakan adalah pengolahan data kuantitatif deskriptif. Skala yang ditentukan akan mendapatkan skor penilaian 1 sampai 5 (sangat tidak setuju sampai sangat setuju). Variabel penelitian ada dua (dua): mata kuliah kewirausahaan dan efisiensi pasar. Setiap vektor memiliki prediktor pada tabel di bawah ini:

\section{Tabel 4. Variabel Operasional}

\begin{tabular}{c|l}
\hline \multicolumn{1}{c|}{ Variabel } & \multicolumn{1}{c}{ Indikator } \\
\hline \multirow{4}{*}{ Orientasi Kewirausahaan } & Inovasi \\
\cline { 2 - 2 } & Pengambilan Resiko \\
\cline { 2 - 2 } & Proaktif \\
\cline { 2 - 2 } Kinerja Usaha & Otonomi \\
\cline { 2 - 2 } & Pertumbuhan Penjualan \\
\cline { 2 - 2 } & Keunggulan Bersaing \\
\cline { 2 - 2 } & Kepuasan Konsumen \\
\hline
\end{tabular}

\section{Hasil dan Pembahasan}

Berdasarkan tabel 5 dapat dilihat beberapa pengukuran mengenai orientasi kewirausahaan yang terdiri dari 5 (lima) metrik, yaitu kreativitas inovatif sebesar 4.09, pengambilan risiko sebesar 3.84, upaya atau proaktif sebesar 3.88, agresivitas kompetitif sebesar 4.52, dan otonomi. Sebesar 4.38. Adapun total rerata dari variabel orientasi kewirausahaan sebesar 4.14 
Tabel 5. Tanggapan responden mengenai orientasi kewirausahaan

\begin{tabular}{|c|c|c|}
\hline ORIENTASI KEWIRAUSAHAAN & $\begin{array}{l}\text { Rata- } \\
\text { Rata }\end{array}$ & Rerata \\
\hline \multicolumn{3}{|l|}{ Inovatif (Inovativeness) } \\
\hline $\begin{array}{l}\text { Saya mendukung perusahaan menekankan pada inovasi, dan } \\
\text { ide kreatif baru }\end{array}$ & 3.97 & \multirow{5}{*}{4.09} \\
\hline $\begin{array}{l}\text { Memiliki investasi lain khusus untuk mengembangkan } \\
\text { produk. }\end{array}$ & 3.88 & \\
\hline Mengajak karyawan dalam melakukan inovasi produk & 4.19 & \\
\hline $\begin{array}{l}\text { Melakukan kegiatan percobaan untuk mendukung tumbuhnya } \\
\text { ide yang baru }\end{array}$ & 4.13 & \\
\hline Membuat inovasi baru yang susah untuk diikuti oleh pesaing & 4.31 & \\
\hline \multicolumn{3}{|l|}{ Mengambil Resiko (Risk Taking) } \\
\hline $\begin{array}{l}\text { Mampu membuat produk melebihi yang ditargetkan agar } \\
\text { menghindari terjadinya permintaan konsumen.yang } \\
\text { bertambah }\end{array}$ & 4.22 & \multirow{4}{*}{3.84} \\
\hline $\begin{array}{l}\text { Menerima permintaan pembuatan produk sesuai dengan } \\
\text { keinginan konsumen. }\end{array}$ & 3.97 & \\
\hline Berani untuk memasuki pasar baru yang berbeda & 4.19 & \\
\hline Membuat investasi yang besar ketika memasarkan produk & 3.00 & \\
\hline \multicolumn{3}{|l|}{ Proaktif (Proactiveness) } \\
\hline $\begin{array}{l}\text { Melakukan kerjasama dengan perusahaan lain untuk } \\
\text { pengembangan produk }\end{array}$ & 4.19 & \multirow{3}{*}{3.88} \\
\hline $\begin{array}{l}\text { Mempromosikan dan mendistribusikan produk melalui media } \\
\text { iklan atau media social }\end{array}$ & 4.09 & \\
\hline $\begin{array}{l}\text { Mampu untuk menarik minat beli konsumen dengan } \\
\text { melakukan promo produk }\end{array}$ & 3.34 & \\
\hline \multicolumn{3}{|l|}{ Otonomi (Autonomy) } \\
\hline Mampu meningkatkan layanan dan kapasitas produksi & 4.31 & \\
\hline $\begin{array}{l}\text { Menyiapkan kotak saran pada bagian kasir atau menyediakan } \\
\text { nomor telepon yang dapat dihubungi oleh konsumen, }\end{array}$ & 4.41 & 4.38 \\
\hline
\end{tabular}

Agresifitas Persaingan (Competitive Aggressiveness)

Dalam persaingan saya merespon aksi yang dimulai oleh 4.44 pesaing

Menjual produk dengan harga yang lebih rendah dari pada 4.59

pesaing

\section{Total Rerata}

\section{Dimensi Orientasi Kewirusahaan}

Arah kewirausahaan suatu perusahaan dianggap sebagai prediktor keberhasilan perusahaan (Kraus et al., 2012). Orientasi kewirausahaan dapat disebut "kepribadian wirausaha" atau "emosi wirausaha" karena orientasi kewirausahaan melekat satu sama lain dan terkait dengan kepekaan (Suci, 2009). Dibandingkan dengan perusahaan yang tidak menggunakan dan menerapkan 
orientasi kewirausahaan, maka perusahaan yang menggunakan dan menerapkan orientasi kewirausahaan tentunya akan memiliki kinerja bisnis yang lebih baik (Wulandary et al., 2018).

Berikut adalah temuan penelitian tentang pengukuran orientasi kewirausahaan yang terdiri dari 5 (lima) metrik, yaitu kreativitas, pengambilan risiko, upaya, agresivitas kompetitif, dan otonomi. Dalam laporan ini, upaya untuk mengembangkan barang atau inovasi baru dan menyusun ide-ide pemasaran yang kreatif untuk memaksimalkan potensi pendapatan menilai jiwa kewirausahaan diarahkan pada indikator kreativitas. Kinerja rata-rata dari 32 metrik kreativitas UMKM adalah 4,09 di tingkat lanjutan. Metrik selanjutnya adalah keberanian mengambil resiko dan dapat dihitung dengan kesediaan UMKM mengambil resiko pasar dengan mengetahui seberapa besar peluang suksesnya, berapa banyak kesalahan dalam mengelola pasarnya, dan keberanian mempertaruhkan potensi keputusan bisnis. Indikator pengambilan risiko rata-rata adalah 3,84 di tingkat yang kuat. Lebih lanjut, metrik proaktif sering dievaluasi dalam analisis ini dengan menemukan pengetahuan tentang dinamika bisnis, prospek anggota UMKM untuk mengejar peluang, serta daya saing dan upaya untuk memprediksi peningkatan dan insentif yang dapat menarik pelanggan. Pada prediktor yang berhasil ini diperoleh nilai rata-rata 3,88 dengan kategori kuat.

Berikutnya adalah prediktor persaingan-semangat. Metrik ini diperluas kepada peserta UMKM dalam studi ini untuk menilai kesediaan mereka menghadapi pesaing, bersedia bernegosiasi dan mengungguli pesaing industri, dan tetap berusaha membangun hubungan dengan pelanggan. Kemitraan yang sehat, masih mencari sumber daya untuk memperluas jangkauan pemasaran. Indeks keseruan bersaing mendapat nilai rata-rata 4,52 termasuk dalam tier sangat kuat. Mengenai langkah terakhir yaitu otonomi, dalam analisis ini peserta UMKM menilai kemampuannya dalam menjalankan usahanya dengan mengevaluasi kemampuannya dalam menjalankan usahanya dengan cara mengontrol seluruh praktek usahanya, sehingga UMKM dapat leluasa dalam memilih pengambilan kebijakan. Dan bebas mengontrol semua aktivitas bisnis. Nilai rata-rata yang diperoleh indeks otonomi adalah 4,38 yang termasuk dalam kategori tinggi. Total skor rata-rata semua indikator pada dimensi "arahan kewirausahaan" adalah 4,14 yang termasuk dalam kategori tinggi, rata-rata tertinggi merupakan indikator semangat bersaing, dan rata-rata terendah merupakan indikator pengambilan risiko.

Tabel 6. Tanggapan responden mengenai Kinerja Kerja

\begin{tabular}{lcc}
\multicolumn{1}{c}{ KINERJA KERJA } & Rata-rata & Rerata \\
\hline \multicolumn{1}{c}{ Pertumbuhan Penjualan } & \multirow{2}{*}{3.62} \\
\cline { 1 - 2 } Target penjualan selalu tercapai & 3.56 & \\
\hline Target keuntungan selalu tercapai & 3.69 & \multirow{2}{*}{4.23} \\
\hline \multicolumn{1}{c}{ Kepuasan Konsumen } & 4.28 & \\
\hline Konsumen selalu puas & 4.19 & \multirow{2}{*}{4.01} \\
\hline Rekan bisnis selalu puas & & \multirow{2}{*}{$\mathbf{3 . 9 5}$}
\end{tabular}


Berdasarkan tabel 6 dapat dilihat beberapa pengukuran mengenai Kinerja Kerja yang terdiri dari 3 (tiga) metrik, yaitu Pertumbuhan Penjualan sebesar 3.62, Kepuasa Konsumen sebesar 4.23 dan Keunggulan Bersaing sebesar 4.01. Adapun total rerata dari Kinerja Kerja ini sebesar 3.95

\section{Dimensi Kinerja Usaha}

Temuan penelitian orientasi kewirausahaan yang melibatkan 3 (tiga) metrik yaitu pengembangan pendapatan, daya saing dan kepuasan konsumen. Variabel adalah hasil yang dihasilkan selama kinerja pasar. Dalam situasi ini, kinerja usaha merupakan reaksi para pelaku UMKM terhadap perusahaannya masing-masing dan kinerja usahanya selama ini. Studi ini menyarankan pertumbuhan pendapatan, daya saing, dan loyalitas konsumen. Perkembangan penjualan harus dilihat dari sudut pandang keuntungan dan target penjualan. Perkembangan penjualan akan ditentukan oleh pendapatan dan penjualan perusahaan, terlepas dari apakah perkembangan terjadi pada setiap siklus output dan apakah itu akan memenuhi kebutuhan hidup melalui industri. Ini adalah upaya untuk menggunakan keluaran masukan secara efisien. Peningkatan pendapatan secara keseluruhan adalah 3,63 termasuk segmen positif.

Berikutnya adalah keunggulan strategis. Ukuran ini membantu untuk mempertimbangkan potensi organisasi untuk membuat barangnya lebih bermanfaat, dan oleh karena itu bersedia menjangkau kelompok sasaran lebih baik daripada para pesaingnya, untuk mendapatkan persaingan dengan perusahaan lain. Untuk manfaat komparatif, skor rata-rata 4,01 berada pada kisaran sukses. Selanjutnya adalah ukuran loyalitas pelanggan. Ukuran ini membantu untuk mempertimbangkan loyalitas konsumen dan mitra. Indeks kepuasan pelanggan rata-rata 4,23 baik-baik saja. Rata-rata keseluruhan dari semua indikator pada dimensi "efisiensi pasar" adalah 3,96 yang berada pada range positif, rata-rata tertinggi pada variabel "kebahagiaan pelanggan", dan rata-rata terendah pada variabel "kenaikan penjualan".

\section{Coefficients $^{\mathbf{a}}$}

\begin{tabular}{lllllll}
\hline & & \multicolumn{2}{l}{$\begin{array}{l}\text { Unstandardized } \\
\text { Coefficients }\end{array}$} & \multicolumn{2}{l}{$\begin{array}{l}\text { Standardized } \\
\text { Coefficients }\end{array}$} & \\
\cline { 3 - 6 } Model & B & Std. Error & Beta & t & Sig. \\
\hline 1 & (Constant) &, 813 & 4,028 & &, 202 &, 850 \\
& Orientasi Kewirausahaan &, 762 &, 976 &, 364 &, 781 &, 478 \\
\hline
\end{tabular}

a. Dependent Variable: Kinerja Usaha

\section{Gambar 1. Hasil Uji Regresi Linier}

Sumber: Data diolah, 2019

Berdasarkan analisis gambar 1 di atas, koefisien regresi variabel jalur kewirausahaan sebesar 0,762 dan konstanta 0,813 . Persamaan regresi berikut dapat dikembangkan, dimana $\mathrm{Y}=0.813+0.726 \mathrm{X} 1$. Selanjutnya dapat disimpulkan bahwa koefisien regresi variabel jalur kewirausahaan sebesar 0,726, yang berarti pengaruh variabel jalur kewirausahaan terhadap output usaha sebesar 0,726. 
Artinya, jika satu unit memunculkan komponen orientasi kewirausahaan maka efisiensi pasar akan meningkat sebesar 0,726. Berdasarkan hasil pengujian, efisiensi pasar vektor dapat ditingkatkan dengan memasukkan variabel orientasi kewirausahaan. Semakin kuat orientasi kewirausahaan peserta UMKM, semakin kuat pula hasil pasarnya.

Hasil penelitian tersebut diperkuat dengan adanya penelitian yang telah dilakukan oleh (Wulandary et al., 2018) memperlihatkan adanya orientasi kewirausahaan mempunyai kedekatan yang signifikan dengan kinerja bisnis, dimana inovasi berhubungan dengan semua variabel kinerja bisnis, kemudian agresivitas dan pengambilan resiko memiliki konektivitas dengan pertumbuhan pada perusahaan dan juga pada kepuasan konsumen, kemudian antusiasme memeiliki konektivitas dengan pertumbuhan pada perusahaan dan juga keunggulan bersaing. Luaran penelitian Helia menampilkan adanya korelasi positif yang signifikan antara orientasi kewirausahaan Malaysia dengan kinerja bisnis UKM. Penelitian ini juga memberikan peluang untuk memperluas penelitian di industri lain, seperti manufaktur, konstruksi, pertanian, dan telekomunikasi (Helia et al., 2015). Temuan lain dari penelitian yang dilakukan oleh (Zain \& Hassan, 2013) menampilkan bahwa terdapat konektivitas yang signifikan antara orientasi kewirausahaan dan kinerja, dan keunggulan bersaing telah diperoleh secara parsial mengatur hubungan antara orientasi kewirausahaan dan kinerja.

\section{Simpulan}

Indikator orientasi kewirausahaan dinilai besar, dengan nilai rata-rata maksimum pada indeks minat bersaing dan nilai rata-rata terendah pada indeks risiko. Ukuran semangat bersaing adalah kesediaan pelaku UMKM di Provinsi Bangka Belitung untuk bersaing dan mengungguli pesaing industri. Karena prediktor ini adalah yang terbaik dibandingkan dengan indikator lain dan indikator risiko terendah, ini bagus. Pemain UKM petualang akan unggul. Peserta UMKM di Belitung Mengka harus menghadapi keadaan yang tidak terduga sehingga dapat mengurangi bahaya pasar. Oleh karena itu, pelaku UMKM harus lebih berani mengambil peluang yang harus dimiliki oleh setiap pelaku UMKM. Output pasar variabel berada dalam kisaran positif, dengan skor rata-rata yang tertinggi pada indikator "kepuasan pelanggan" dan skor rata-rata yang terendah pada indikator "kenaikan penjualan". UMKM Provinsi Bangka Belitung akan terus memiliki customer support yang memuaskan, sehingga mengingat variabel ini merupakan variabel yang paling rendah maka akan berpengaruh positif terhadap pertumbuhan penjualan. Arah kewirausahaan berdampak positif. Semakin kuat orientasi kewirausahaan peserta UMKM, maka hasil perusahaan akan semakin baik.

\section{Daftar Pustaka}

Ameliawati, R., \& Nugraheni, R. (2015). Analisis pengaruh kepemimpinan, lingkungan kerja dan kompensasi terhadap kinerja karyawan (Studi pada CV. Fan Jaya Logam Kaliwungu) (Doctoral Dissertation, Fakultas Ekonomika Dan Bisnis).

BPS Provinsi Bangka Belitung. (2019). Berita Resmi Statistik. Bps.Go.Id, 27, 1- 
16. https://jakarta.bps.go.id/pressrelease/2019/11/01/375/tingkatpenghunian-kamar--tpk--hotel--berbintang-dki-jakarta-pada-bulanseptember-2019-mencapai-58-97-persen.html

Fairoz, F. M., Hirobumi, T., \& Tanaka, Y. (2010). Entrepreneurial Orientation and Business Performance of Small and Medium Scale Enterprises of Hambantota District Sri Lanka Fauzul. Asian Social Science, 6(3), 34-46. https://doi.org/10.5539/ass.v6n3p34

Helia, R., Farida, N., \& Prabawani, B. (2015). Pengaruh Orientasi Pasar dan Orientasi Kewirausahaan Terhadap Keunggulan Bersaing Melalui Inovasi Produk sebagai Variabel Antara (Studi Kasus pada IKM Batik di Kampung Batik Laweyan, Solo). Journal Of Social And Political Of Science, 1-10.

Kraus, S., Rigtering, J. P. C., Hughes, M., \& Hosman, V. (2012). Entrepreneurial orientation and the business performance of SMEs: A quantitative study from the Netherlands. Review of Managerial Science, 6(2), 161-182. https://doi.org/10.1007/s11846-011-0062-9

Kristiyanti, M., \& Rahmasari, L. (2015). Website sebagai media pemasaran produkproduk unggulan umkm di Kota Semarang. Jurnal Aplikasi Manajemen, 13(2), 186-196.

Rahmana, A., Iriani, Y., \& Rienna, O. (2012). Strategi Pengembangan Usaha Kecil Menengah Sektor Industri Pengolahan. Jurnal Teknik Industri, 13(1), 14. https://doi.org/10.22219/jtiumm.vol13.no1.14-21

Sofyan, S. (2017). Orientasi Kewirausahaan, Kinerja Inovasi Dan Kinerja Pemasaran Usaha Mikro, Kecil Dan Menengah Pada Sentra Industri Tas Desa Kadugenep. JBRM Tirtayasa, 1(1), 65-80.

Suci, R. P. (2009). Peningkatan Kinerja Melalui Orientasi Kewirausahaan, Kemampuan Manajemen, dan Strategi Bisnis (Studi pada Industri Kecil Menengah Bordir di Jawa Timur). Jurnal Manajemen Dan Wirausaha, 11(1), 46-58. https://doi.org/10.9744/jmk.11.1.pp.46-58

Sudarsono, B. (2015). Analisis Pengaruh Orientasi Kewirausahaan terhadap Strategi Bisnis dalam Meningkatkan Kinerja Usaha Kecil dan Menengah (UKM). Orbith: Majalah Ilmiah Pengembangan Rekayasa dan Sosial, 11(1).

Wahyu, D., \& Ranto, P. (2016). Pengaruh Orientasi Kewirausahaan Terhadap Kinerja UMKM Bidang Kuliner Di Yogyakarta. Jurnal Bisnis, Manajemen, Dan Akuntansi, III(2), 1-11.

Wulandary, A., Burhanuddin, B., \& Priatna, W. B. (2018). Kinerja Wirausaha Dan Orientasi Kewirausahaan Pelaku Umkm Olahan Abon Ikan. Jurnal AGRISEP : Kajian Masalah Sosial Ekonomi Pertanian Dan Agribisnis, 17(2), 129-138. https://doi.org/10.31186/jagrisep.17.2.129-138

Zain, M., \& Hassan, A. E. (2013). The Impact of Corporate Entrepreneurship on Company Growth in a Hostile Business Environment Mohamed. In Journal of Chemical Information and Modeling (Vol. 53, Issue 9). 